Document ID \#P109194

\title{
QUANTIFYING THE BEHAVIORAL RESPONSE OF SPAWNING CHUM SALMON TO ELEVATED DISCHARGES FROM BONNEVILLE DAM, COLUMBIA RIVER
}

\section{ANNUAL REPORT 2005-2006}

Prepared by:

\author{
Kenneth F. Tiffan, Craig A. Haskell, and Tobias J. Kock \\ U.S. Geological Survey \\ Western Fisheries Research Center \\ Columbia River Research Laboratory \\ 5501 A Cook-Underwood Rd. \\ Cook, Washington 98605, USA
}

Prepared for:

\author{
U.S. Department of Energy \\ Bonneville Power Administration \\ Environment, Fish and Wildlife Department \\ P.O. Box 3621 \\ Portland, OR 97208-3621 \\ Project Number 199900301 \\ Contracts 19562, 29307, 34979 \\ http://www.efw.bpa.gov/searchpublications/
}

November 2008 


\section{Table of Contents}

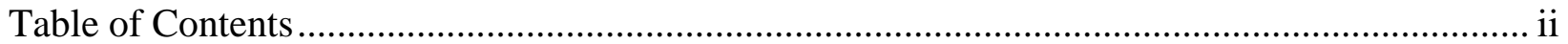

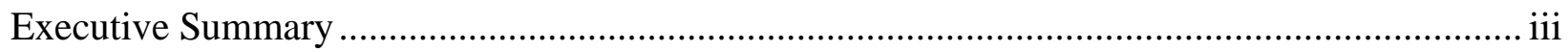

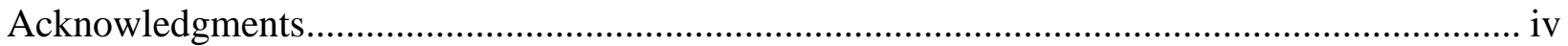

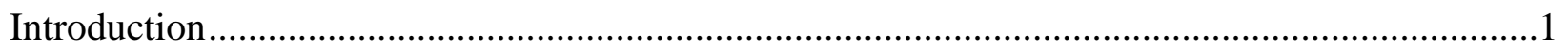

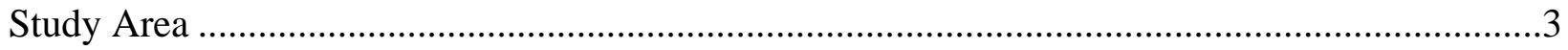

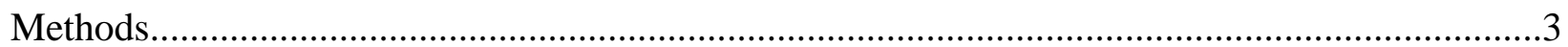

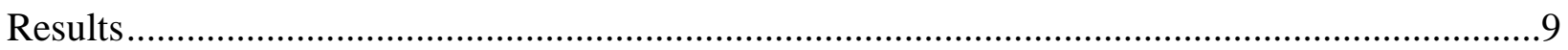

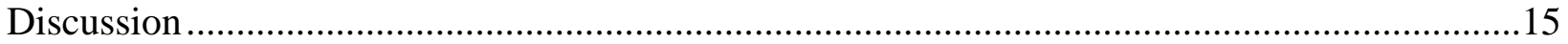

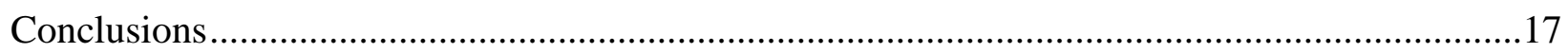

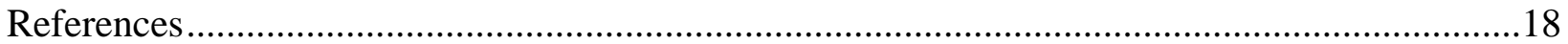




\section{Executive Summary}

Chum salmon Oncorhynchus keta that spawn in main-stem habitats below Bonneville Dam on the Columbia River, USA, are periodically subjected to elevated discharges that may alter spawning behavior. We investigated behavioral responses of spawning chum salmon to increased water velocities associated with experimental increases in tailwater elevation using acoustic telemetry and a dual-frequency identification sonar. Chum salmon primarily remained near their redds at base tailwater elevations (3.5 m above mean sea level), but displayed different movement and behavioral responses as elevations were increased to either 4.1 or $4.7 \mathrm{~m}$ for 8 -h periods. When velocities remained suitable $(<0.8 \mathrm{~m} / \mathrm{s})$ during elevated tailwater tests, female chum salmon remained near their redds but exhibited reduced digging activity as water velocities increased. However, when velocities exceeded $0.8 \mathrm{~m} / \mathrm{s}$, the females that remained on their redds exhibited increased swimming activity and digging virtually ceased. Female and male chum salmon that left their redds when velocities became unsuitable moved mean distances ranging from 32 to $58 \mathrm{~m}$ to occupy suitable velocities, but returned to their redds after tailwaters returned to base levels. Spawning events (i.e., egg deposition) were observed for five of nine pairs of chum salmon following tests indicating any disruptions to normal behavior caused by elevated tailwaters were likely temporary. We believe a chum salmon's decision to either remain on, or leave, its redd during periods of unsuitably high water velocities reflects time invested in the redd and the associated energetic costs it is willing to incur. 


\section{Acknowledgements}

We thank our colleagues at the U.S. Geological Survey’s Columbia River Research Laboratory whose efforts contributed to the success of this study. We acknowledge the U.S. Army Corps of Engineers, the Bonneville Power Administration, the Technical Management Team, and the Fish Passage Advisory Committee for granting approval for this study and providing elevated tailwaters at Bonneville Dam. We also acknowledge the support of the Washington Department of Fish and Wildlife, the Oregon Department of Fish and Wildlife, the U.S. Fish and Wildlife Service, and the Pacific Northwest National Laboratory, which were cooperators on a larger study of chum salmon in the lower Columbia River. Reviews by Jill Hardiman, Ty Hatton, Dave Pflug, and an anonymous reviewer greatly improved this manuscript. This study was funded by the Bonneville Power Administration and administered by Debbie Docherty. Any use of trade names is for descriptive purposes only and does not imply endorsement by the U.S. Government. 


\section{Introduction}

In unimpounded rivers, Pacific salmon (Oncorhynchus spp.) typically spawn under relatively stable stream flows, with exceptions occurring during periodic precipitation events. In contrast, hydroelectric development has often resulted in an artificial hydrograph characterized by rapid changes in discharge and tailwater elevation that occur on a daily, or even an hourly basis, due to power generation (Cushman 1985; Moog 1993). Consequently, populations of Pacific salmon that are known to spawn in main-stem habitats below hydroelectric dams face the risks of changing habitat suitability, potential redd dewatering, and uncertain spawning success (Hamilton and Buell 1976; Chapman et al. 1986; Dauble et al. 1999; Garland et al. 2003; Connor and Pflug 2004; McMichael et al. 2005). Although the direct effects of a variable hydrograph, such as redd dewatering are apparent, specific effects on spawning behavior remain largely unexplored.

Chum salmon (O. keta) that spawn below Bonneville Dam on the Columbia River are particularly vulnerable to the effects of water level fluctuations. Although chum salmon generally spawn in smaller tributaries (Johnson et al. 1997), many fish spawn in main-stem habitats below Bonneville Dam near Ives Island (Tomaro et al. 2007; Figure 1). The primary spawning area near Ives Island is shallow and sensitive to changes in water level caused by hydroelectric power generation at Bonneville Dam. In the past, fluctuating water levels have dewatered redds and changed the amount of available spawning habitat (Garland et al. 2003). To minimize these effects, fishery managers attempt to maintain a stable tailwater elevation at Bonneville Dam of 3.5 m (above mean sea level) during spawning, which ensures adequate water is provided to the primary chum salmon spawning area below the mouth of Hamilton Creek (Figure 1). Given the uncertainty of winter precipitation and water supply, this strategy has been effective at restricting spawning to a specific riverbed elevation and providing minimum spawning flows that have the greatest chance of being maintained through egg incubation and fry emergence.

However, managing the lower Columbia River for a stable tailwater elevation does not provide much operational flexibility at Bonneville Dam, which has little storage capacity. When river discharges increase due to rain events, the traditional approach has been to pass excess water at night to maintain stable tailwater elevations during the daytime. The underlying assumption of this strategy, referred to as reverse load following, is that fish do not spawn at night. However, Tiffan et al. (2005) showed that this assumption is false by documenting nighttime spawning by chum salmon in the Ives Island area. Similarly, McMichael et al. (2005) reported nighttime spawning by Chinook salmon (O. tshawytscha) in the Columbia River, indicating that diel spawning may be a common occurrence in Pacific salmon. During the latter portion of the chum spawning period in December 2003 and 2004, discharges from Bonneville Dam increased from an average of 3,398 $\mathrm{m}^{3} / \mathrm{s}$ (tailwater elevation $\sim 3.5 \mathrm{~m}$ above mean sea level) during the day to over $5,664 \mathrm{~m}^{3} / \mathrm{s}$ (tailwater elevation $\sim 5.1 \mathrm{~m}$ ) at night, with peak discharges of $7,080 \mathrm{~m}^{3} / \mathrm{s}$ (tailwater elevation $\sim 6.1 \mathrm{~m}$ ). This caused concern among fishery managers regarding the potential effects of these high discharges on this population of spawning chum salmon, which is listed under the Endangered Species Act (National Oceanic and Atmospheric Administration 1999). 

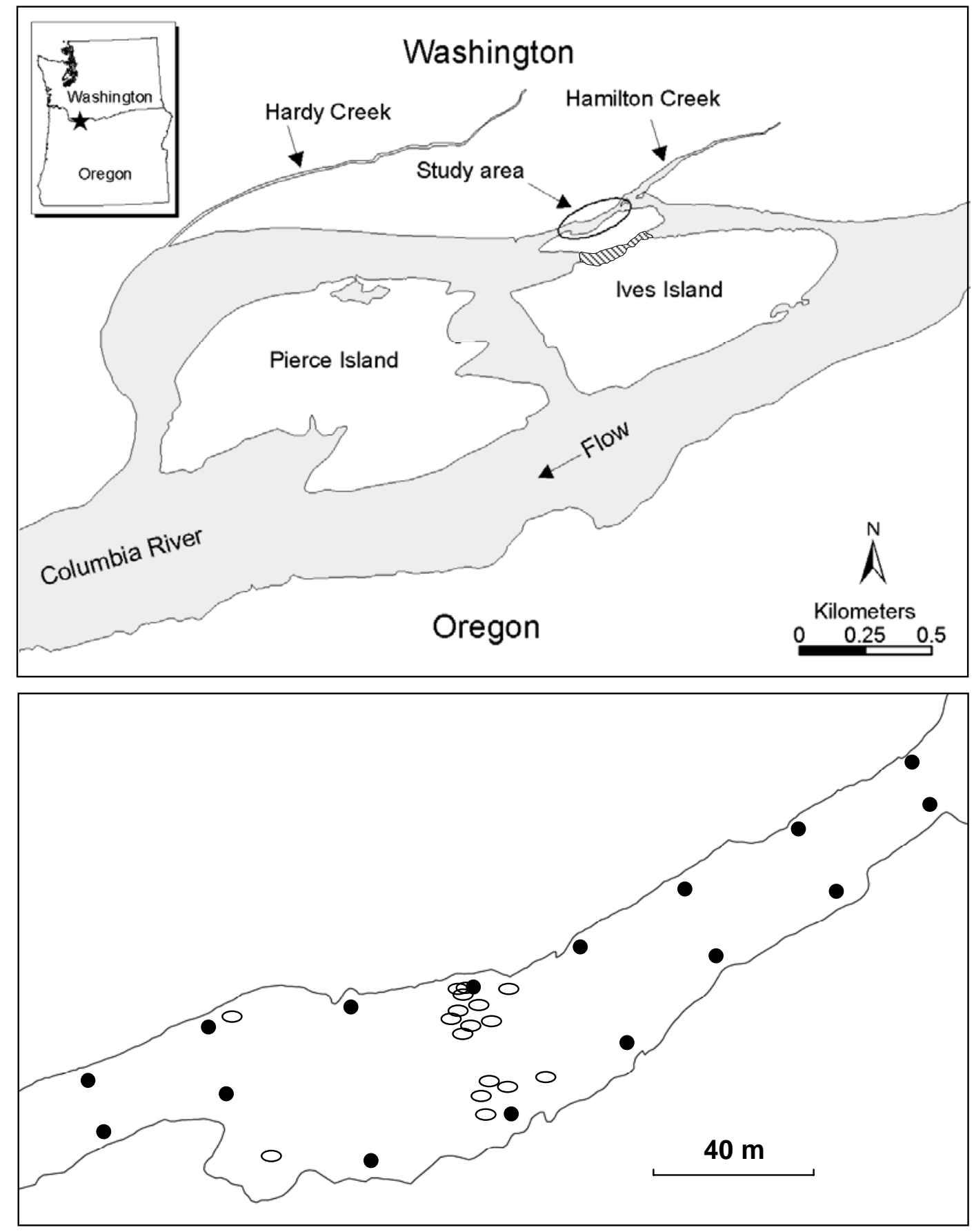

Figure 1. A map of our study area (top panel) where the behavioral responses of spawning chum salmon to elevated tailwaters was evaluated in 2005. Also shown is the spawning area on the north side of Ives Island (hatched area) that contains water at a tailwater elevation of $4.1 \mathrm{~m}$. Bonneville Dam is located approximately $5 \mathrm{~km}$ upstream. The bottom panel shows an expanded view of the study area with locations of hydrophones (black circles) and redd locations (open ovals) of acoustically-tagged chum salmon. 
We hypothesized that increased water velocities associated with elevated tailwaters might alter chum salmon spawning behavior if water velocities at redd locations increased beyond the range of suitability ( $>0.8 \mathrm{~m} / \mathrm{s}$; Salo 1991). In 2005, we investigated the movement and behavioral responses of spawning chum salmon at Ives Island to increased tailwater elevations at Bonneville Dam. We used acoustic telemetry to determine if the higher velocities associated with increased tailwater elevations caused fish to leave their redds. We related the duration fish were away from redds and the distances moved to water velocities estimated from a two-dimensional hydrodynamic model. Finally, we described specific changes in spawning behavior (e.g., nest digging; swimming activity) during elevated-tailwater tests using a dual-frequency identification sonar (DIDSON).

\section{Study Area}

We conducted our study from 16 November to 8 December 2005 to coincide with the majority of chum salmon spawning in our study area (Tomaro et al. 2007). A small amount of information was collected during this same time frame in 2006 as well to supplement data collected in 2005. We studied wild chum salmon spawning behavior in a small side channel of the Columbia River near Ives Island located about $5 \mathrm{~km}$ downstream of Bonneville Dam (Figure 1). This channel is located directly below the mouth of Hamilton Creek between the Washington shore and Ives Island on the Columbia River at river kilometer 229 (as measured from the river's mouth). This channel is about $250 \mathrm{~m}$ long, has a mean width of $44 \mathrm{~m}$, and longitudinal gradient of $<1 \%$. The bed is composed of gravel $(4-75 \mathrm{~mm})$ and cobble (76-150 $\mathrm{mm}$ ) substrate, depths do not exceed $1 \mathrm{~m}$, and water velocities are generally $<1 \mathrm{~m} / \mathrm{s}$ at a Bonneville Dam tailwater elevation of $3.5 \mathrm{~m}$ (as measured at U.S. Geological Survey gauge 14128870). When Hamilton Creek is dry, flow through this channel is only maintained by discharges from Bonneville Dam that exceed 3,400 m³/s (Garland et al. 2003). A significant amount of chum salmon spawning has occurred in this area since 1998 (Garland et al. 2003; Tomaro et al. 2007).

\section{Methods}

\section{Elevated tailwater tests}

Discharges at Bonneville Dam are managed to achieve a specific tailwater elevation during the chum salmon spawning period. Because tailwater elevation is the metric used for decision making by fishery and hydropower managers, we describe tests of elevated discharge in terms of tailwater elevations at Bonneville Dam. We requested increases in Bonneville Dam tailwater elevations from $3.5 \mathrm{~m}$ (the base elevation provided during spawning) to either 4.1 or 4.7 $\mathrm{m}$ to evaluate the response of spawning chum salmon to corresponding increases in water velocity. The 4.1-m tailwater elevation was selected because past hydrodynamic and habitat modeling showed that at this elevation water begins to flow into a channel on the north side of Ives Island (Figure 1) where chum salmon spawning was documented in 1998 and 1999 during high flows (van der Naald et al. 1999, 2001; Garland et al. 2003). This channel is otherwise dry at a tailwater elevation of $3.5 \mathrm{~m}$. We also believed that water velocities in our study area at this tailwater elevation would be intermediate to the 3.5 and 4.7-m tailwater elevations. We selected the 4.7-m tailwater because hydrodynamic modeling indicated that most velocities in our study 
area at this elevation would no longer be suitable for spawning chum salmon. Furthermore, this elevation corresponded to the conditions observed in 1998 and 1999 when late arriving chum salmon avoided our study area and moved to the north side of Ives Island to spawn in more suitable habitat (van der Naald et al. 1999, 2001). The 4.7-m tailwater elevation was also the maximum we could reasonably expect to obtain from hydropower and fishery managers at that time of year.

We requested five tests each at tailwater elevations of 4.1 and $4.7 \mathrm{~m}$. Each test lasted $8 \mathrm{~h}$ and was scheduled during either the day or night due to logistical constraints of water availability, hydroelectric power generation priorities, and compatibility with other field work being conducted in the area. We assumed the diel timing of tests would not influence our results because Tiffan et al. (2005) found no diel-related differences in chum salmon spawning behavior in this area. We selected an 8-h test duration to ensure fish had ample time to elicit a response to increased velocities associated with elevated tailwaters. Daytime tests conducted at a 4.1-m tailwater elevation proceeded by ramping tailwater elevations from $3.5 \mathrm{~m}$ up to $4.1 \mathrm{~m}$ between 0700 to $0800 \mathrm{~h}$, holding the tailwater steady until $1600 \mathrm{~h}$, then ramping back down to $3.5 \mathrm{~m}$ by 1700 h. Daytime tests conducted at a 4.7-m tailwater elevation were similar except tailwater elevations were ramped up to $4.1 \mathrm{~m}$ from 0600 to $0700 \mathrm{~h}$ and then up to $4.7 \mathrm{~m}$ from 0700 to 0800 h. Elevations were decreased in similar hourly increments at $1600 \mathrm{~h}$. Nighttime tests were conducted from 1600 to $0200 \mathrm{~h}$ the following morning with 1- or 2-h ramping periods for 4.1 and $4.7 \mathrm{~m}$ tailwater elevations, respectively.

\section{Fish collection and tagging}

We used acoustic telemetry to monitor the movements of chum salmon in response to base and elevated tailwaters. We collected adult chum salmon from the study area using a beach seine the day before each daytime test and the day of each nighttime test. Fish collected and tagged prior to a specific test were only evaluated in that test and were not used in subsequent tests. Our approach was to tag gravid females that had initiated redd construction as evidenced by some erosion on the anal fin and presence of eggs (determined by external probing of abdomen). We assumed if female chum salmon had initiated redd construction in the area they would have a greater likelihood of remaining in the study area during a test. Because of the low number of suitable female chum salmon, we also tagged a small number of mature males as well.

Prior to tagging, we made a qualitative visual assessment of each fish and tagged those that were in the best condition and fully gravid, or mature in the case of male fish. On each day of capture, we tagged 1-4 fish by placing them individually in a large, water-filled cooler, measuring them, and gastrically inserting an acoustic tag (model 795E-R; Hydroacoustic Technology, Inc.). Tags were cylindrical and measured $53 \mathrm{~mm}$ in length, $19 \mathrm{~mm}$ in diameter, and were rounded on one end to facilitate gastric implantation. Tags weighed $18 \mathrm{~g}$ in air and had a minimum life expectancy of $7 \mathrm{~d}$. All tags operated at a frequency of $307.5 \mathrm{kHz}$ and had a pulse width of $1 \mathrm{~ms}$ but were uniquely identifiable by pulse rate, which we varied by 10 -ms intervals (range=1010 to $1410 \mathrm{~ms}$ ). After acoustic tagging, fish were then tagged with a colored Floy tag on either side of the dorsal fin. Each group of fish used in an individual test was given a distinct Floy tag color so we could identify them if they were subsequently recaptured. We were able to 
tag and release individual fish in about $45 \mathrm{~s}$. Tagging of groups of fish was generally completed by $1000 \mathrm{~h}$ each day.

\section{Acoustic telemetry system}

To monitor the movement of tagged chum salmon, we deployed an array of 16 omnidirectional hydrophones (model 590; Hydroacoustic Technology, Inc.) in our study area, which we refer to as the spawning channel (Figure 1). Eight hydrophones were deployed on each side of the channel and were spaced $40 \mathrm{~m}$ apart along the shoreline in water less than $0.6 \mathrm{~m}$ deep. All hydrophones were mounted $15 \mathrm{~cm}$ above the river bottom on concrete blocks that were secured to the riverbed with rebar stakes. Hydrophones were oriented parallel to the river bottom and pointed toward the center of the channel. The cross-channel distance between hydrophone pairs varied from about 15 to $40 \mathrm{~m}$. The geographic position of each hydrophone was measured using a Trimble 5700 RTK (Real Time Kinematic) GPS (Global Positioning System), which had a horizontal accuracy of $\pm 1.45 \mathrm{~cm}$ and a vertical accuracy of $\pm 2.45 \mathrm{~cm}$. A network of eight steel cables was suspended over the channel at hydrophone locations to support hydrophone cables that ran from each hydrophone to a single acoustic tag receiver (model 290; Hydroacoustic Technology, Inc.) housed in a mobile office trailer on the shore. By suspending hydrophone cables, we attempted to minimize stress on hydrophone cables caused by high water velocities and damage by floating debris. We continuously measured the in-water speed of sound within our hydrophone array using a sound velocimeter (CTD Plus, Applied Microsystems, Inc.).

Preliminary testing using both stationary and towed tags indicated the precision of estimated tag locations in relation to actual locations was $0.51 \mathrm{~m}$ and accuracy of estimated tag positions was $1.8 \mathrm{~m}$ ( range: 0.07 to $7.84 \mathrm{~m}$, standard error $<0.01$ ). Although our acoustic telemetry system was capable of generating three-dimensional positions, we were unconcerned with the elevation component of fish positions as the water depth was relatively shallow $(<1 \mathrm{~m})$ and we expected tagged fish to remain near the riverbed. We monitored the movements of acoustically-tagged chum salmon every $1 \mathrm{~s}$ (the ping rate of our acoustic tags) before, during, and after elevated tailwater tests. Pre-test monitoring comprised about $22 \mathrm{~h}$ of observation for daytime tests and about $6 \mathrm{~h}$ of observation for nighttime tests. Post-test monitoring duration varied from 1 to $7 \mathrm{~h}$ for both daytime and nighttime tests. Pre- and post-test monitoring durations varied due to fish tagging, test schedules, and availability of personnel.

\section{DIDSON}

We used a DIDSON (Sound Metrics, Inc.) to collect continuous behavioral information on spawning chum salmon before, during, and after elevated tailwater tests. The DIDSON produces video-like images using sound instead of light and enables one to collect information such as digging, spawning, and swimming activity during the day as well as at night. We opportunistically selected pairs of chum salmon from the population at large for which the females were actively constructing redds. We positioned the DIDSON to view the fish from the side at a distance of about 4-5 m, which provided about a 2.5-m horizontal field of view (see Tiffan et al. 2005 for additional information on DIDSON settings and deployment). We began continuous data collection on fish at least $4 \mathrm{~h}$ prior to the beginning of a test and continued for 2$4 \mathrm{~h}$ after a test. 


\section{Data analysis}

Acoustic telemetry.-We processed acoustic telemetry data by first separating valid tag detections from each hydrophone from ambient noise detections. Data were then filtered to remove erroneous detections caused by multipath. Multipath is the result of multiple returns from an individual tag caused by the acoustic signal bouncing off the water surface or hard structures before being received by a hydrophone. A multipath filter within the HTI Mark Tags software eliminates linear groups of tag returns arriving slightly after the initial direct-path returns. The software first records all returns for each tag and then separates initial tag returns from mulitpath returns. All processed files are then combined into a database and positions are calculated by the acoustic system using an algorithm based on hydrophone position, the speed of sound in water as measured in our array, and the time differential of acoustic signals received by different hydrophones in the array.

We limited our analyses of chum salmon movements to fish that we assumed were associated with redds, which was not known with certainty at the time of tagging. To estimate redd locations, we conducted a moving window analysis using ArcMap GIS software (ESRI, Inc.) to determine the highest density of point locations within a 1-m grid, using a circular neighborhood with a 2-m radius. This was based on the expectation that the highest density of fish locations would be associated with the redd and display a tight, clustered pattern (e.g., Figure 2). We used the centroid of this area to define the redd location and to reference distances moved by fish during base and elevated tailwater conditions. Euclidean distances between individual point locations and the redd location were calculated using the Pythagorean Theorem. We arbitrarily used $2 \mathrm{~m}$ as a reasonable distance a fish could be from the redd location and still be considered associated with the redd. This resulted in an area larger than the redd sizes reported for chum salmon $\left(2.3 \mathrm{~m}^{2}\right.$, Burner 1951; $2.1 \mathrm{~m}^{2}$, Tiffan et al. 2005) but accounted for the larger area that a female chum will occupy to chase away intruding fish in defense of her redd (Schroder 1981; Tiffan et al. 2005). Fish that did not subjectively appear to be spending time in a central location at any time during data collection were deemed not to be associated with a redd and were removed from further analysis (e.g., Figure 2). We were able to visually confirm that two of our acoustically-tagged fish were associated with redds, and the pattern of their locations fit our criteria. As mentioned previously, each fish was only used once in a test and we ultimately included 14 female and 3 male chum salmon in our analyses.

Water velocities were estimated at our study site, using the results of past twodimensional hydrodynamic modeling of our study area (Garland et al. 2003). River discharges

were modeled in 142- $\mathrm{m}^{3} / \mathrm{s}$ increments at Bonneville Dam over a range of 3,257 to $4,814 \mathrm{~m}^{3} / \mathrm{s}$ and a constant Hamilton Creek discharge of $5\left(\mathrm{~m}^{3 /} \mathrm{s}\right)$ using the River2D hydrodynamic model (Ghanem et al. 1996). Water velocities estimated from these simulations were imported into a GIS to create raster surfaces that were interpolated to a $1-\mathrm{m}^{2}$ resolution. We developed a simple linear regression model between Bonneville Dam discharge (hourly data) and tailwater elevation (5-min data) to subsequently predict discharge at every 5-min interval. We were then able to identify the hydrodynamic model run that best matched each 5-min Bonneville Dam tailwater elevation. All redd and fish location data were then merged with corresponding hydrodynamic model velocity data to extract an estimated water velocity at each fish location over time. However, we lagged our fish location data by 30 min because it took that amount of time for 

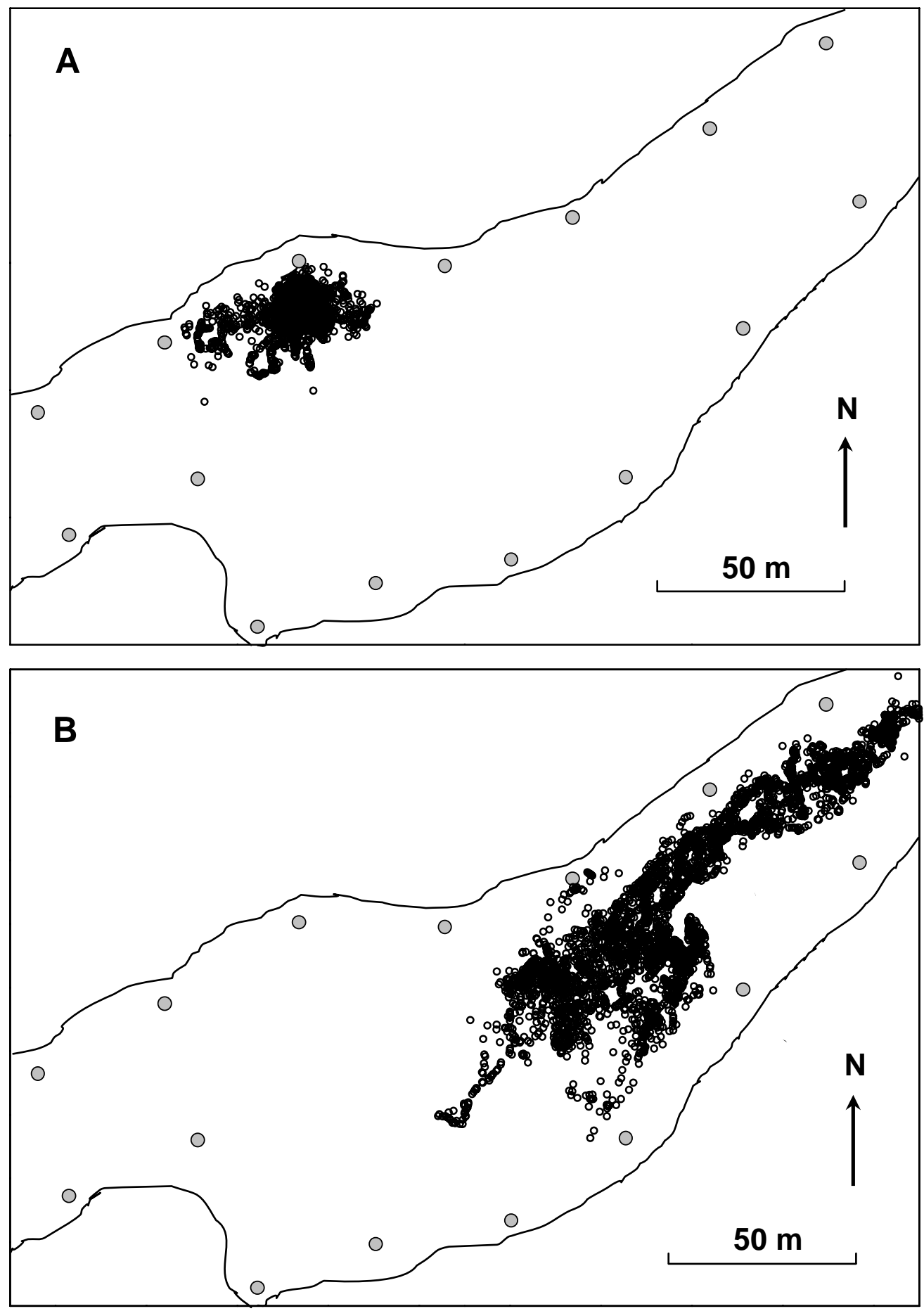

Figure 2. An example of the pattern of female chum salmon locations over an 8-h period that we used to determine whether a fish had a redd (panel A) or did not have a redd (panel B) at Ives Island, 2005. Hydrophone locations are indicated by the gray circles. 
operational changes at Bonneville Dam to be realized at our study area $5 \mathrm{~km}$ downstream. In all analyses, we did not include data collected during the ramping periods.

To quantify fish movements, we first calculated the proportion of observations within 2 $\mathrm{m}$ of the redd centroid at base and elevated tailwaters for each fish. This served as a measure of how closely a fish was associated with it's redd under each test condition. We also calculated similar proportions for observations within $5 \mathrm{~m}$ of the redd to describe a larger area over which fish may move. This would result when a fish chases away an intruding fish. Any locations farther than $5 \mathrm{~m}$ from the redd centroid were deemed to be excursions made by fish away from the redd. We calculated the proportion of observations comprising excursions as well as the mean excursion distance during base and elevated tailwaters. We calculated mean water velocities for each fish observed within $2 \mathrm{~m}$ of the redd and for excursions made during base and elevated tailwaters. We define velocities used by chum salmon as being suitable if they were less than $0.8 \mathrm{~m} / \mathrm{s}$ (Salo 1991). The large sample sizes of our acoustic telemetry data obtained from the tags emitting signals at 1 -s intervals $(\mathrm{N}=12,211-82,284)$ precluded any meaningful statistical comparisons because the high power to detect differences would have made every comparison significant.

DIDSON. - Data files of chum salmon spawning behavior collected with the DIDSON were reviewed to obtain information on female digging activity, time spent on the redd, swimming activity, and the incidence of spawning events. We refer to a spawning event as one of the 4-6 egg deposition occurrences typical in the chum salmon spawning cycle (Helle 1981). We determined the number of digs (in 15-min intervals) made by the female fish to construct her nest and then calculated means for each fish during periods of base and elevated tailwaters. We made a distinction between digs made to construct a nest and digs made to cover eggs after a spawning event following the observations of Tautz and Groot (1975) and Tiffan et al. (2005). Covering digs were excluded from analyses since they comprised such a small portion of the total digging time but had the potential to inflate mean values because of their greater numbers per unit time (e.g., 70/15 min). We measured the velocities experienced by fish at base and elevated tailwaters by tracking the movement rate of at least 10 particles in the water column passing through the DIDSON's field of view under each condition. The distance each particle moved was measured using the DIDSON software measuring tool, which was then divided by the elapsed time to determine its velocity. No particles were tracked during the 1- or 2-h ramping periods, and time of collecting velocity data during a test was lagged by the time it took tailwater increases at Bonneville Dam to be realized at Ives Island ( 30 min). Chum salmon digging activity was related to water velocity using a broken-stick regression because the data suggested the existence of a velocity threshold. For this analysis, we used a least-squares method to find the slopes and intercepts of the two regression lines that minimized the total sum of squares (Plumb et al. 2006).

We calculated the time each female chum salmon spent in the DIDSON's field of view during each test to determine if fish left their redd, and for how long, under elevated tailwaters. A fish was considered absent from the field of view if it was gone for a minimum of $2 \mathrm{~min}$. The amount of time each fish was absent was summed and expressed as a percentage of the total time of each test. We examined changes in swimming activity by counting the number of tailbeats/min each female chum salmon displayed during base and elevated tailwaters. We 
randomly selected ten 1-min periods from each tailwater condition and counted the number of tailbeats (a full back and forth flexure of the tail) in each period. The mean number of tailbeats/min were calculated for each period and related to the corresponding water velocity using linear regression. Finally, we summarized the number of spawning events that occurred before, during, or after elevated tailwater tests. Spawning events were readily observable with the DIDSON as indicated by the male fish moving along side the female fish and remaining motionless for at least $5 \mathrm{~s}$ followed by a period of rapid covering digs made by the female (Tiffan et al. 2005).

\section{Results}

We conducted nine elevated tailwater tests from 16 November to 8 December 2005 . One of the original 10 tests requested was cancelled. We requested four tests with a maximum Bonneville Dam tailwater elevation of $4.1 \mathrm{~m}$ and five tests with a maximum tailwater elevation of $4.7 \mathrm{~m}$. Observed tailwater elevations were generally close to requested tailwater elevations. Exceptions occurred on 17 November 2005 when a scheduled 4.7-m test only reached a maximum elevation of $4.5 \mathrm{~m}$, and on 19 November 2005 when a $4.1-\mathrm{m}$ test only reached a maximum elevation of $4.0 \mathrm{~m}$. Although three of the tests were conducted during the day and six were conducted at night, we observed no diel-related differences in fish behavior during our study.

Although 31 female and nine male chum salmon were initially tagged, only 14 female and three male chum salmon fit our criteria for being associated with a redd and were included in our analyses. Female chum salmon averaged $73 \mathrm{~cm}$ (range $=67$ to $80 \mathrm{~cm}$ ) in length and male lengths averaged $82 \mathrm{~cm}$ (range $=81$ to $83 \mathrm{~cm}$ ). The mean number of locations obtained on female chum salmon using acoustic telemetry was 47,836 (range $=12,111$ to 85,419) and 21,612 (range $=18,438$ to 26,010) for male chum salmon.

Female chum salmon were more closely associated with redds than male fish at base tailwater elevations. For the 14 female fish we analyzed, the mean proportion of observations within $2 \mathrm{~m}$ of the redd centroid was 0.74 (range $=0.27$ to 0.97 ), but females were generally within $5 \mathrm{~m}$ of the redd (mean proportion $=0.92$, range $=0.71$ to 100.0; Table 1 ). Excursions made more than $5 \mathrm{~m}$ from the redd accounted for $8 \%$ (range $=0$ to $29 \%$ ) of observations for female chum salmon during base conditions. The mean excursion distance was $18 \mathrm{~m}$ (range $=6$ to $54 \mathrm{~m}$ ). The three male fish we analyzed moved over a greater area near their redds, and the mean proportion of observations within $2 \mathrm{~m}$ of the redd centroid was 0.42 (range $=0.40$ to 0.51 ), but $82 \%$ (range $=67$ to $90 \%$ ) of male fish locations were within $5 \mathrm{~m}$ from the redd (Table 1 ). Male fish made excursions away from their redds that averaged $16 \mathrm{~m}$ (range $=9$ to $25 \mathrm{~m}$ ). At base tailwater elevations, the mean velocity experienced by female chum salmon fish at redd locations was $0.26 \mathrm{~m} / \mathrm{s}$ (range $=0.001$ to $0.44 \mathrm{~m} / \mathrm{s}$ ), and $0.19 \mathrm{~m} / \mathrm{s}$ (range $=0.04$ to $0.38 \mathrm{~m} / \mathrm{s}$ ) for male chum salmon.

During elevated tailwater tests, eight female chum salmon stayed on their redds in velocities that were near $0.8 \mathrm{~m} / \mathrm{s}$, or less. At base levels, these fish were exposed to mean velocities of $0.23 \mathrm{~m} / \mathrm{s}$, which increased to $0.66 \mathrm{~m} / \mathrm{s}$ at elevated tailwater levels. Although there 
Table 1. Summary of the movements made by acoustically-tagged chum salmon and the velocities they occupied during elevated tailwater tests at Ives Island, 2005. Ranges are shown in parentheses. Results for female chum salmon that occupied unsuitable redd velocities during tests are shown for those that moved from, and stayed on, their redds.

\begin{tabular}{|c|c|c|c|c|c|c|}
\hline \multirow[b]{4}{*}{ Metric } & \multicolumn{4}{|c|}{ Females } & & \\
\hline & \multirow{3}{*}{$\begin{array}{l}\text { Base } \\
\text { tailwater } \\
(N=14)\end{array}$} & \multicolumn{3}{|c|}{ Elevated tailwater } & \multicolumn{2}{|c|}{ Males } \\
\hline & & \multirow{2}{*}{$\begin{array}{l}\text { Suitable redd } \\
\text { velocities } \\
\quad(N=8)\end{array}$} & \multicolumn{2}{|c|}{ Unsuitable redd velocities } & \multirow{2}{*}{$\begin{array}{l}\text { Base } \\
\text { Tailwater } \\
(N=3)\end{array}$} & \multirow{2}{*}{$\begin{array}{c}\text { Elevated } \\
\text { tailwater } \\
(N=3)\end{array}$} \\
\hline & & & Moved $(N=3)$ & Stayed $(N=3)$ & & \\
\hline $\begin{array}{l}\text { Mean proportion } \\
\text { of observations } \\
<2 \text { m from redd }\end{array}$ & $0.74(0.27-0.97)$ & $0.63(0.23-0.90)$ & $0.23(0-0.46)$ & $0.82(0.69-0.92)$ & $0.42(0.40-0.51)$ & $0.19(0-0.45)$ \\
\hline $\begin{array}{l}\text { Mean proportion } \\
\text { of observations } \\
<5 \text { m from redd }\end{array}$ & $0.92(0.71-100)$ & $0.94(0.66-100)$ & $0.34(0-0.58)$ & 1.0 & $0.82(0.67-0.90)$ & $0.43(0-0.89)$ \\
\hline $\begin{array}{l}\text { Mean proportion } \\
\text { of observations } \\
>5 \mathrm{~m} \text { from redd }\end{array}$ & $0.08(0-0.29)$ & $0.06(0-0.34)$ & $0.66(0.42-100)$ & --- & $0.18(0.10-0.33)$ & 0.57 (0.10-0.99) \\
\hline $\begin{array}{l}\text { Mean excursion } \\
\text { distance }(\mathrm{m})\end{array}$ & $18(6-54)$ & $11(6-35)$ & $49(40-54)$ & --- & $16(9-25)$ & $41(32-58)$ \\
\hline $\begin{array}{l}\text { Mean velocity at } \\
\text { redd }(\mathrm{m} / \mathrm{s})\end{array}$ & $0.26(0-0.44)$ & $0.66(0.34-0.83)$ & $1.37(1.18-1.51)$ & $1.19(0.92-1.63)$ & $0.19(0.04-0.38)$ & $0.84(0.64-1.21)$ \\
\hline $\begin{array}{l}\text { Mean velocity } \\
\text { away from redd } \\
(\mathrm{m} / \mathrm{s})\end{array}$ & $0.28(0.03-0.43)$ & $0.69(0.47-0.84)$ & $0.78(0.69-0.89)$ & --- & $0.21(0.07-0.36)$ & $0.74(0.64-0.92)$ \\
\hline
\end{tabular}


was a slightly lower mean proportion of observations within $2 \mathrm{~m}$ of the redd centroid (mean = 0.63 , range $=0.23$ to 0.90 ) at these velocities, fish were generally within $5 \mathrm{~m}$ of their redd (mean proportion $=0.94$, range $=0.66$ to 100 ; Table 1 ). Female chum salmon that made excursions from their redds under relatively suitable velocities during tests traveled a mean distance of $11 \mathrm{~m}$ (range $=6$ to $35 \mathrm{~m}$ ). Of the six female chum salmon exposed to velocities $>0.8 \mathrm{~m} / \mathrm{s}$ during elevated tailwater tests, half remained over their redds in high velocities (mean $=1.19 \mathrm{~m} / \mathrm{s}$, range $=0.92-1.63 \mathrm{~m} / \mathrm{s}$ ) and half moved away from their redd to lower velocities (mean $=0.78 \mathrm{~m} / \mathrm{s}$, range $=0.69-0.89 \mathrm{~m} / \mathrm{s}$ ) that were generally suitable. The three female chum salmon that moved occupied locations that averaged $49 \mathrm{~m}$ (range $=40$ to $54 \mathrm{~m}$ ) away from their redds, but returned to their redds after tailwaters returned to base levels. Figure 3 shows examples of two different movement responses we observed for female chum salmon during base and elevated tailwater periods.

All male chum salmon moved substantial distances away from their redds during elevated tailwater tests (Table 1). These fish experienced increases in mean velocities from $0.19 \mathrm{~m} / \mathrm{s}$ at base conditions to $0.84 \mathrm{~m} / \mathrm{s}$ at elevated tailwaters. Male chum salmon responded by moving a mean distance of $41 \mathrm{~m}$ to occupy velocities that averaged $0.74 \mathrm{~m} / \mathrm{s}$. Following tests, male fish returned to their redds.

We used the DIDSON to observe seven pairs of spawning chum salmon in 2005 and two pairs in 2006. At base elevations, female chum salmon dug at a mean rate of 7.8 digs/15 min (range $=4.3$ to 13.5 digs $/ 15 \mathrm{~min}$ ) under a mean velocity of $0.28 \mathrm{~m} / \mathrm{s}$ (range $=0.19$ to $0.40 \mathrm{~m} / \mathrm{s}$ ), which were all suitable (i.e., $<0.80 \mathrm{~m} / \mathrm{s}$; Table 2 ). At elevated tailwaters, mean digging rate decreased to 2.1 digs $15 / \mathrm{min}$ (range $=0.003$ to 8.4 digs $/ 15 \mathrm{~min}$ ) as the mean velocity increased to $0.80 \mathrm{~m} / \mathrm{s}$ (range $=0.27$ to $1.33 \mathrm{~m} / \mathrm{s}$ ). With one exception, the highest digging rates observed at elevated tailwaters were for fish whose redds remained in suitable velocities. Very little digging occurred at elevated tailwaters when velocities over redds exceeded $0.8 \mathrm{~m} / \mathrm{s}$. Broken stick regression revealed a velocity threshold of $0.61 \mathrm{~m} / \mathrm{s}$ above which redd digging activity was significantly reduced and close to zero (Figure 4).

Female chum salmon observed with the DIDSON showed movement responses similar to those of acoustically-tagged fish under elevated tailwaters. At base elevations, fish were observed in the field of view most of the time (mean $=89.2 \%$, range $=64.3$ to $100 \%$; Table 2 ). As tailwaters and velocities increased, the amount of time fish were observed in the field of view dropped to a mean of $48.4 \%$, but varied substantially (range $=1.9$ to $99.4 \%$ ). Chum salmon either stayed on their redds or left for various amounts of time. Fish that stayed on their redds under elevated tailwaters generally exhibited decreased digging activity, particularly if their redds were in unsuitably high velocities (Table 2).

Swimming activity of female chum salmon varied directly with water velocity (Figure 5). As velocities rose with increases in tailwater elevations, chum salmon exhibited an increase in the frequency of tailbeats/min necessary to maintain position on their redds. The relationship between swimming activity and water velocity was: tailbeats $/ \mathrm{min}=51.562 \cdot$ velocity $(\mathrm{m} / \mathrm{s})+$ $20.372\left(r^{2}=0.92\right)$. 


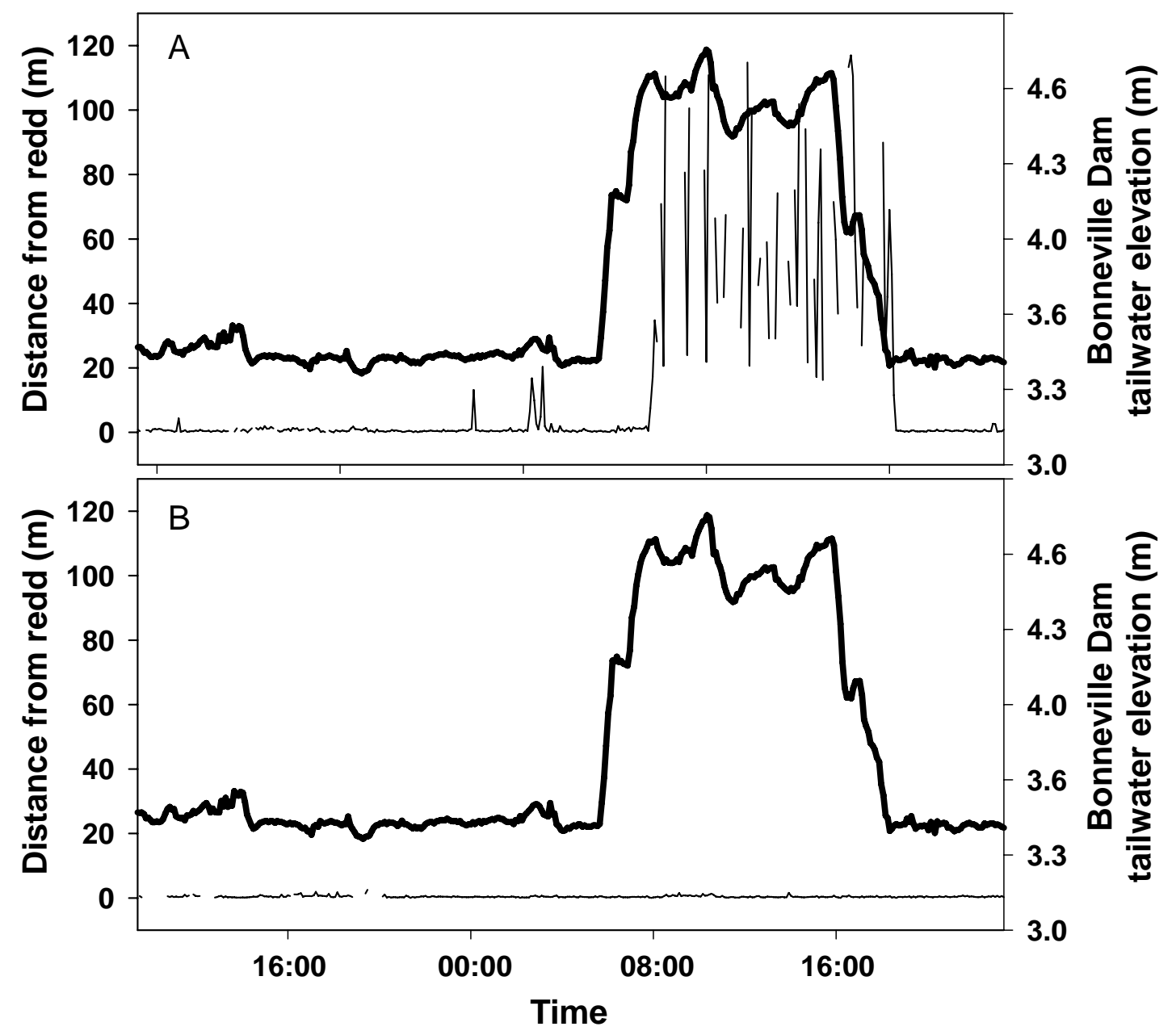

Figure 3. Two examples of different movement patterns displayed by acoustically-tagged female chum salmon in response to elevated tailwaters from Bonneville Dam, 2005. Panel A shows a few excursions made before tailwater elevations increased (heavy line) and then substantial movement (fine line) at increased elevations. Panel B shows relatively little movement before, during, and after the elevated tailwater test. 
Table 2. Summary of female chum salmon spawning behavior and water velocity collected with a DIDSON at base and elevated tailwaters at Ives Island, 2005.

\begin{tabular}{|c|c|c|c|c|c|c|c|c|c|c|}
\hline \multirow[b]{2}{*}{$\begin{array}{c}\text { Tailwater } \\
\text { elevation } \\
(\mathrm{m})\end{array}$} & \multirow[b]{2}{*}{$\begin{array}{l}\text { Chum } \\
\text { pair }\end{array}$} & \multicolumn{4}{|c|}{ Base tailwater } & \multicolumn{4}{|c|}{ Elevated tailwater } & \multirow[b]{2}{*}{$\begin{array}{c}\text { Observed } \\
\text { spawning } \\
\text { event }\end{array}$} \\
\hline & & $\begin{array}{c}\text { Mean } \\
\text { digs/ } \\
15 \text { min }\end{array}$ & $\begin{array}{c}\text { Mean } \\
\text { velocity } \\
(\mathrm{m} / \mathrm{s})\end{array}$ & $\begin{array}{l}\% \text { time in } \\
\text { field of } \\
\text { view }\end{array}$ & $\begin{array}{c}\text { Mean } \\
\text { tailbeats/ } \\
\text { min }\end{array}$ & $\begin{array}{c}\text { Mean } \\
\text { digs/ } \\
15 \text { min }\end{array}$ & $\begin{array}{c}\text { Mean } \\
\text { velocity } \\
(\mathrm{m} / \mathrm{s})\end{array}$ & $\begin{array}{c}\% \text { time in } \\
\text { field of } \\
\text { view }\end{array}$ & $\begin{array}{c}\text { Mean } \\
\text { tailbeats } \\
\text { /min }\end{array}$ & \\
\hline 4.1 & 1 & 8.4 & 0.19 & 99.3 & 34.0 & 3.8 & 0.27 & 98.7 & 39.0 & Post test \\
\hline 4.0 & 2 & 5.9 & 0.40 & 84.3 & 39.1 & 2.3 & 0.61 & 1.9 & 50.0 & Post test \\
\hline 4.7 & 3 & 7.5 & 0.26 & 99.4 & 30.5 & 0.8 & 0.92 & 15.6 & 75.5 & None \\
\hline 4.5 & 4 & 7.4 & 0.30 & 64.3 & 34.7 & 0.7 & 0.92 & 4.8 & 83.0 & Post test \\
\hline 4.7 & 5 & 6.6 & 0.27 & 100.0 & 36.8 & 1.3 & 1.01 & 99.4 & 68.9 & Pre test \\
\hline 4.7 & 6 & 8.7 & 0.33 & 100.0 & 32.0 & 0.7 & 1.18 & 43.7 & 78.2 & Post test \\
\hline 4.7 & 7 & 4.3 & 0.36 & 95.4 & 37.9 & 0.8 & 1.33 & 64.6 & 80.5 & Post test \\
\hline 4.3 & $8^{\mathrm{a}}$ & 8.2 & 0.25 & 74.3 & 32.0 & 8.4 & 0.37 & 89.8 & 41.7 & During \\
\hline \multirow[t]{2}{*}{4.9} & $9^{\mathrm{a}}$ & 13.5 & 0.20 & 86.1 & 24.7 & 0.03 & 0.56 & 17.5 & 51.1 & Pre test \\
\hline & Means & 7.8 & 0.28 & 89.2 & 33.5 & 2.1 & 0.80 & 48.8 & 63.1 & \\
\hline
\end{tabular}

\footnotetext{
${ }^{a}$ These fish were observed during flow tests conducted in 2006
} 


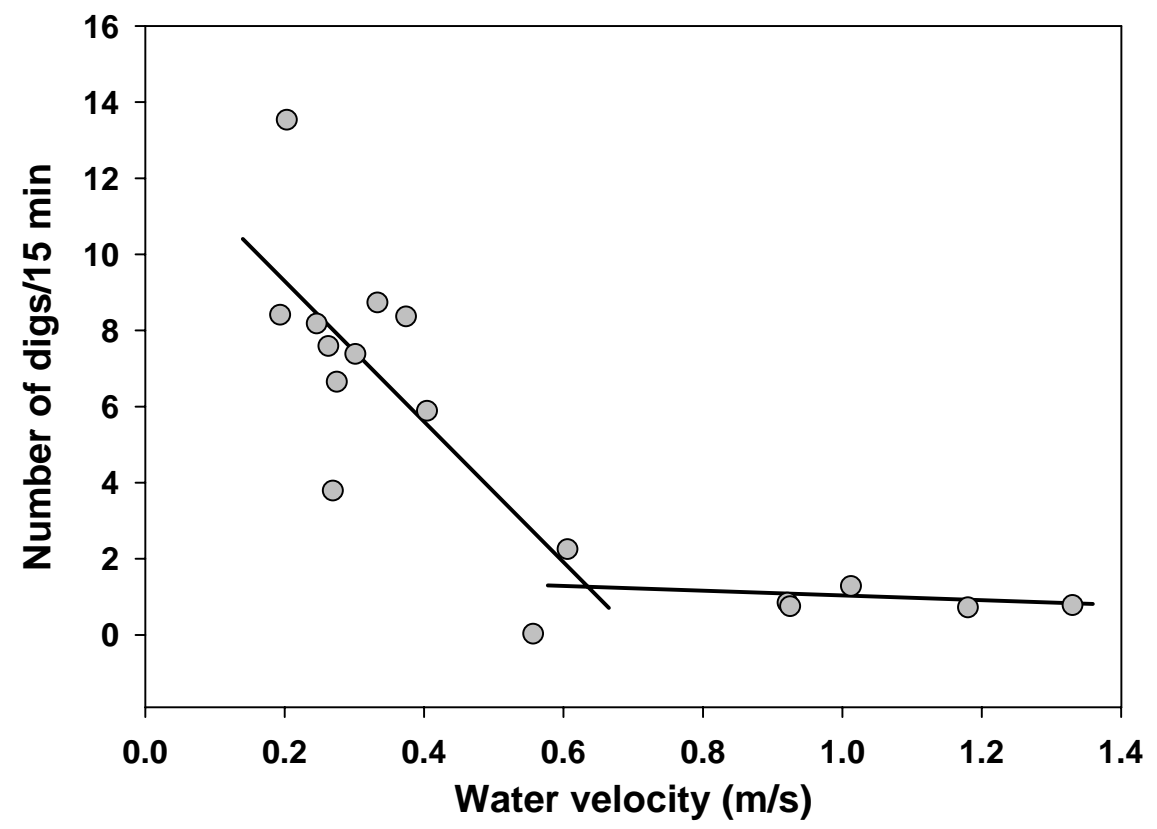

Figure 4. A broken-stick regression between female chum salmon redd digging activity and water velocity observed with a DIDSON during elevated tailwater tests at Ives Island, 20052006. The cut-off velocity between the two models occurred at $0.61 \mathrm{~m} / \mathrm{s}$. The regression equation for digging that occurred at velocities below the cut-off was: digs $/ 15 \mathrm{~min}=-20.41$. velocity +13.58 , and the equation for digging that occurred above the cut-off was: digs $/ 15 \mathrm{~min}=$ $0.33 \cdot$ velocity +1.23 . The overall $r^{2}$ for both regressions was 0.78 .

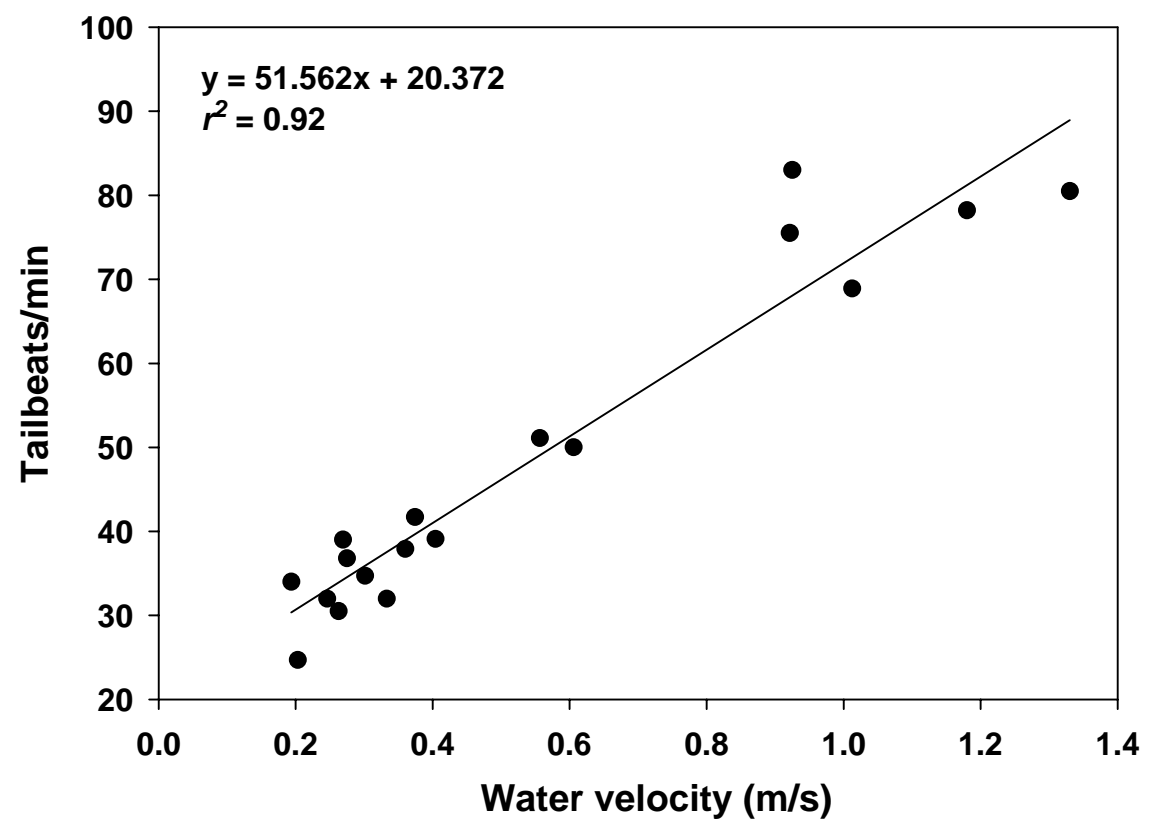

Figure 5. The relationship between female chum salmon swimming activity (as measured in tailbeats/min) and water velocity at Ives Island, 2005-2006. 
Of the nine pairs of chum salmon observed with the DIDSON, eight completed spawning events. Two events were observed under base tailwaters before a test, one shortly after a test began, and five following tests after tailwaters declined to base levels (Table 2). The pair of chum salmon that completed a spawning event during a test experienced suitable velocities over their redd throughout the base and test periods. The female fish from this pair also exhibited the highest digging frequency of all fish observed during a test.

\section{Discussion}

It is important to recognize the limitations that may have affected our study results. Although tagging may have affected chum salmon behavior, we observed two Floy-tagged fish digging on their redds within 15 min of their release after tagging. This indicates that chum salmon have the capacity to recover rapidly from handling and tagging. Furthermore, we observed no immediate or short-term (e.g., within 48 h) mortality of tagged fish in our study area. Similar handling of adult chum salmon during a combination of acoustic and jaw tagging in the Skagit River resulted in no mortalities or behavioral affects (Dave Pflug, Seattle City and Light, personal communication) suggesting our handling had minimal effects. In fact, many of our tagged fish were captured in the week following their initial testing and showed signs that they had spawned. A number of uncertainties associated with the fish we tagged ultimately influenced our final sample sizes. The number of fish we tagged was limited by the availability of suitable females in our study area, which was relatively low. After a fish was tagged, we did not know for certain whether it would stay in our study area or move into nearby tributaries to spawn. Although we tried to select fish that were gravid and that had fin wear indicative of spawning activity, we did not know with certainty that it had an established redd in our study area or how many spawning events it had completed. In spite of our small sample sizes, we believe our results provide insight into the effects elevated tailwaters and velocities have on spawning chum salmon.

Most chum salmon we observed remained in the vicinity of their redds at base tailwaters, which was expected since it was under these conditions that redd sites were initially selected. Under base conditions, all velocities were suitable and fish were presumably engaged in redd construction and courtship. Our 2-m criterion for defining the area a fish would most likely occupy over it's redd may have been conservative as increasing this distance to $5 \mathrm{~m}$ included most fish locations. Female chum salmon move off their redds when chasing intruding fish (Schroder 1981; Tautz and Groot 1975; Tiffan et al. 2005) or when one or more intruding males enter the redd to fight with the courting male. We have observed this behavior on numerous occasions at Ives Island, during which times the female fish will leave for extended periods of time. This may explain the excursions we observed for female chum salmon. Male chum salmon tended to move over a larger area than females at base tailwater elevations. This was likely due to the more time they spent chasing away intruding fish, often over greater distances. Additionally, males could afford to spend more time away from the redd since they were not involved in redd construction.

Under elevated tailwaters, increases in water velocity elicited two movement responses in chum salmon depending on the magnitude of the velocity at the redd location. First, female chum salmon remained on their redds and exhibited no appreciable change in movement if 
velocities remained suitable. However, half the females that experienced unsuitable velocities during periods of elevated tailwaters also remained on their redds and held position in the swift current. In contrast, the other half of the females moved away from their redd to areas of lower, more suitable velocities until water levels declined. This movement explains the large excursion distances observed for these fish. All three male fish observed also left their redds for lower velocities, but there was a lower threshold velocity $(\sim 0.65 \mathrm{~m} / \mathrm{s})$ for two of the fish. Because male chum salmon may have less of an investment in the redd, they may be more likely to leave the redd at lower velocities.

We believe the behavioral responses chum salmon displayed to increased velocities associated with elevated tailwaters reflect a complex interaction between investment in a redd, and the costs of either remaining or leaving. Because redds are constructed almost exclusively by females, it is reasonable that they would have a greater investment in the redd than males and thus be more likely to remain near their redds as velocities increase. This was confirmed for most female chum salmon exposed to elevated, but suitable, velocities over their redds, and for half of the females exposed to unsuitable velocities. However, the consequences of remaining near their redds were reduced digging activity and increased swimming activity, particularly at velocities $>0.8 \mathrm{~m} / \mathrm{s}$. It is plausible that if these fish were in the early stages of redd construction and had relatively high energy reserves, they may have had a greater capacity to maintain position on their redds during high velocities. For the three females that left their redds at elevated tailwaters and moved to lower velocities, the potential saving in energy expenditure came at the expense of cessation in spawning activity until velocities decreased and fish returned to their redds. These fish may have been further along in completing their redd and may not have had the energy to withstand the high redd velocities during tests.

Increases in water velocity at elevated tailwaters likely increased the energetic costs for the female chum salmon that remained on their redds. McVeigh et al. (2007) recently reported the energetic costs associated with various chum salmon spawning behaviors. They found that holding position on the redd was the most important component of the overall daily energy budget of chum salmon. The increase in swimming activity (i.e., tailbeat frequency) we observed at higher velocities suggests that chum salmon were incurring greater energetic costs to maintain position on their redds. Similarly, Tsuda et al. (2006) found a substantial increase in tailbeat frequency of spawning chum salmon when flows were high in a Japanese river, and speculated that significant depletion of energy reserves may occur under such conditions. The three female chum salmon that left their redds when velocities exceeded $1 \mathrm{~m} / \mathrm{s}$ may have done so to reduce energy expenditure. Alternatively, they may not have been able to sustain (for extended periods) the swimming speed needed to physically maintain their position at the redd locations.

Female chum salmon that remained on their redds at elevated tailwaters also exhibited reduced redd digging activity. These results agree with those of Tsuda et al. (2006) who found a similar decrease in typical chum salmon spawning behaviors and a complete cessation of nest digging during a high discharge event. In that study, flows increased water depths by $80 \mathrm{~cm}$, but the authors were unable to measure accompanying velocities. Chum salmon in our study exhibited reduced digging activity as velocities increased to $0.61 \mathrm{~m} / \mathrm{s}$, and digging virtually ceased at velocities $>0.9 \mathrm{~m} / \mathrm{s}$. Digging is the most energetically expensive spawning act female 
chum salmon engage in (McVeigh et al. 2007), so reducing digging frequency may be another strategy for conserving energy during periods of unsuitable velocities. Since chum salmon arrive at their spawning grounds with a finite amount of energy, any additional energetic costs incurred may increase the risk of not completing their spawning cycle.

Increased velocities that result in the displacement of chum salmon from redds and decreased spawning activity may further delay the completion of spawning. Delay of spawning represents a risk to fish that may only live for 9-15 d after reaching the spawning area (Koski, 1975). If chum salmon use all their available energy to hold position either on, or away from, their redds at elevated tailwaters, they may not complete spawning before they die. Furthermore, Tsuda et al. (2006) speculated that spawning delay caused by elevated discharges may result in lack of oviposition (Barlaup et al. 1994) or reduced egg viability of over-ripe eggs (DeGaudemar and Beall 1998). This may be particularly true as the duration of delay increases. In the Tsuda et al. (2006) study, fish spent more than a week in high discharges without spawning. However in our relatively short-duration tests, the changes we observed in digging frequency and hence the time it took to complete a redd probably did not affect chum salmon spawning success. As previously mentioned, five pairs of fish observed with the DIDSON did spawn following tests so any interruptions in their spawning process caused by elevated tailwaters appeared to be temporary. However, chum salmon will construct 4-6 spawning nests that compose the redd (Helle 1981), which may take 30-40 h to complete (Salo 1991). Therefore, the cumulative effects of spawning delays become more important as the duration and frequency of these events increase.

\section{Conclusions}

Our study was the first to experimentally manipulate discharges in a large main-stem river to measure the subsequent response of chum salmon spawning downstream. The location of individual redds in our study area determined the magnitude of the velocity experienced by fish during elevated tailwater tests that ultimately influenced their behavior. We showed that as velocities increased beyond those initially selected at redd sites, behaviors such as swimming activity increased, digging decreased, and some chum salmon left their redds. Chum salmon in our study showed both resilience and high fidelity to their redds as evidenced by those fish that remained on their redd in spite of high velocities and those that returned after elevated tailwater tests. Velocities that exceed $1 \mathrm{~m} / \mathrm{s}$ will increase the energetic costs to fish and will effectively halt normal spawning and courtship behaviors until velocities subside. The capacity of chum salmon to withstand high discharge events and successfully complete their spawning cycle remains largely unexplored but would likely diminish with increasing magnitude, duration, and frequency of such events. 


\section{References}

Barlaup B.T., Lura H., and Sagrov H. 1994. Inter- and intra-specific variability in female salmonid spawning behaviour. Canadian Journal of Zoology 72: 636-642.

Burner C.J. 1951. Characteristics of spawning nests of Columbia River salmon. Fishery Bulletin 52: 97-110.

Chapman D.W., Weitkamp D.E., Welch T.L., Dell M.B., and Schadt T.H. 1986. Effects of river flow on the distribution of Chinook salmon redds. Transactions of the American Fisheries Society 115: 537-547.

Connor E.J., and Pflug D.E. 2004. Changes in the distribution and density of pink, chum, and Chinook salmon spawning in the upper Skagit River in response to flow management measures. North American Journal of Fisheries Management 24:835-852.

Cushman R.M. 1985. Review of ecological effects of rapidly varying flows downstream from hydroelectric facilities. North American Journal of Fisheries Management 5: 330-339.

Dauble D.D., Johnson R.L., and Garcia A.P. 1999. Fall Chinook salmon spawning in the tailraces of lower Snake River hydroelectric projects. Transactions of the American Fisheries Society 128: 672-679.

De Gaudemar B., and Beall E. 1998. Effects of overripening on spawning behaviour and reproductive success of Atlantic salmon females spawning in a controlled flow channel. Journal of Fish Biology 53: 434-446.

Garland R.D., Tiffan K.F., Rondorf D.W., Skalicky J., and Anglin D.R. 2003. Assessment of chum and fall Chinook salmon spawning habitat near Ives and Pierce islands in the Columbia River. Report to the Bonneville Power Administration, Contract 00004701, Portland, Oregon.

Ghanem A.H., Steffler P.M., Hicks F.E., and Katopodis C. 1996. Two-dimensional hydraulic simulation of physical habitat conditions in flowing streams. Regulated Rivers: Research and Management 12: 185-200.

Hamilton R., and Buell J.W. 1976. Effects of modified hydrology on Campbell River salmonids. Canada Fisheries and Marine Service, Technical Report Series Pac/T-76-20, Ottawa.

Helle J.H. 1981. Significance of the stock concept in artificial propagation of salmonids in Alaska. Canadian Journal of Fisheries and Aquatic Sciences 38: 1665-1671.

Johnson O.W., Grant W.S., Kope R.G., Neely K., Waknitz F.W., and Waples R.S. 1997. Status review of chum salmon from Washington, Oregon, and California. NOAA Technical Memorandom NMFS-NWFSC-32, Seattle, Washington. 
Koski K.V. 1975. The survival and fitness of two stocks of chum salmon (Oncorhynchus keta) from egg deposition to emergence in a controlled-stream environment at Big Beef Creek. Ph.D. Dissertation, University of Washington, Seattle, WA, USA.

McMichael G.A., Rakowski C.L., James B.B., and Lucas J.A. 2005. Estimated fall Chinook salmon survival to emergence in dewatered redds in a shallow side channel of the Columbia River. North American Journal of Fisheries Management 25: 876-884.

McVeigh B.R., Healey M.C., and Wolfe F. 2007. Energy expenditures during spawning by chum salmon Oncorhynchus keta (Walbaum) in British Columbia. Journal of Fish Biology 71: 1696-1713.

Moog O. 1993. Quantification of daily peak hydropower effects on aquatic fauna and management to minimize environmental impacts. Regulated Rivers: Research and Management 8:5-14.

National Oceanic and Atmospheric Administration. 1999. Endangered and threatened species: threatened status for two ESUs of chum salmon in Washington and Oregon, for two ESUs of steelhead in Washington and Oregon, and for Ozette Lake sockeye salmon in Washington. Federal Register 64: 14507-14517.

Plumb J.M., Perry R.W., Adams N.S., and Rondorf D.W. 2006. The effects of river impoundment and hatchery rearing on the migration behavior of juvenile steelhead in the lower Snake River, Washington. North American Journal of Fisheries Management 26: 438-452.

Salo E.O. 1991. Life history of chum salmon (Oncorhynchus keta). In Pacific Salmon Life Histories, Groot C, Margolis L (eds). UBC Press, Vancouver, British Columbia: pp. 231309.

Schroder S.L. 1981. The influence of intrasexual competition on the distribution of chum salmon in an experimental stream. In Proceedings of the Salmon and Trout Migratory Behavior Symposium, Brannon EL, Salo EO (eds). School of Fisheries, University of Washington: pp. 275-285.

Tautz A.F., and Groot C. 1975. Spawning behavior of chum salmon (Oncorhynchus keta) and rainbow trout (Salmo gairdneri). Journal of the Fisheries Research Board of Canada 32: 633-642.

Tiffan K.F., Rondorf D.W., and Skalicky J.J. 2005. Diel spawning behavior of chum salmon in the Columbia River. Transactions of the American Fisheries Society 134: 892-900.

Tomaro L., van der Naald W., Brooks R., Jones T., and Friesen T. 2007. Evaluation of chum and fall Chinook salmon spawning below Bonneville Dam. Report to the Bonneville Power Administration, Contract 00029512, Portland, Oregon. 
Tsuda Y., Kawabe R., Tanaka H., Mitsunaga Y., Hiraishi T., Yamamoto K., and Nashimoto K. 2006. Monitoring the spawning behaviour of chum salmon with an acceleration data logger. Ecology of Freshwater Fish 15: 264-274.

van der Naald W., Clark R., and Spellman B. 1999. Evaluation of fall Chinook and chum salmon spawning below Bonneville Dam. Report to the Bonneville Power Administration, Contract 15007-1, Portland, Oregon.

van der Naald W., Spellman B., and Clark R. 2001. Evaluation of fall Chinook and chum salmon spawning below Bonneville Dam, The Dalles, John Day, and McNary dams. Report to the Bonneville Power Administration, Contract 15007-2, Portland, Oregon. 